\title{
Pulsatile-flow mechanical circulatory support (MCS) as a bridge to transplantation or recovery. Single-centre experience with the POLCAS system in 2014
}

\author{
Mariusz Kuśmierczyk ${ }^{1}$, Mateusz Kućc ${ }^{1}$, Jarosław Szymański ${ }^{1}$, Andrzej Juraszek ${ }^{1}$, Piotr Kołsut ${ }^{1}$, \\ Krzysztof Kuśmierski ${ }^{1}$, Tomasz Zieliński ${ }^{2}$, Małgorzata Sobieszczańska-Małek ${ }^{2}$, Ewa Sitkowska-Rysiak ${ }^{3}$ \\ ${ }^{1}$ Department of Cardiac Surgery and Transplantation, Institute of Cardiology, Warsaw, Poland \\ 2Department of Heart Failure and Transplantation, Institute of Cardiology, Warsaw, Poland \\ ${ }^{3}$ Department of Anaesthesiology, Institute of Cardiology, Warsaw, Poland \\ Kardiochirurgia i Torakochirurgia Polska 2015; 12 (3): 228-232
}

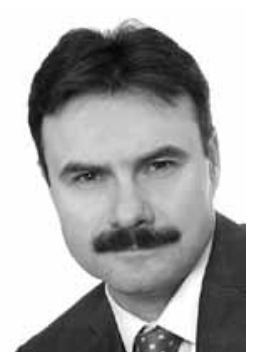

\begin{abstract}
Introduction: Mechanical circulatory support (MCS) is a recognised method of treatment for patients with end-stage chronic or acute heart failure. The POLCAS pulsatile-flow system has been used in our institution for 15 years. Currently, it is being widely replaced by continuous-flow mechanical circulatory support equipment of the second and third generations (HeartMatell, HeartWare). The MCS presented in this study is associated with a significant risk of complications and its use is increasingly considered controversial. The aim of the study was an evaluation of the results of treatment utilising the POLCAS MCS system at our institution in 2014.

Material and methods: The POLCAS system was implanted in 12 patients aged $16-63$ years ( $42 \pm 17$ years) during a period of 12 months (from January to December, 2014). Full-blown cardiogenic shock was observed in all patients before MCS implantation. Four of the analysed patients (33\%) required prior circulatory support with other devices: IABP $(n=2)$ or ECMO $(n=2)$. Episodes of cardiac arrest were reported in three patients; three other patients experienced serious arrhythmias, which accelerated the decision to implant MCS. The presented data was retrospectively obtained from the CliniNET system of the Institute of Cardiology. OpenOffice Calc spreadsheet was used for data analysis.

Results: Average MCS time was 41 days \pm 25 (from 15 to 91 days). Survival until transplantation or explantation was 91.67\%. The most frequent complications following the therapy were: cardiac tamponade or bleeding requiring an intervention - $25 \%(n=3)$, renal failure requiring dialysis $-25 \%$ $(n=3)$, ischaemic stroke associated with the MCS $-16.6 \%$ $(n=2)$, bacteraemia $-16.6 \%(n=2)$, and wound infection $-8 \%$ $(n=1)$. No malfunctions of the MCS system were reported. Early survival in patients who completed the MCS therapy, defined as discharge, amounted to $63.6 \%(n=7)$.
\end{abstract}

\section{Streszczenie}

Wstęp: Mechaniczne wspomaganie krążenia (mechanical circulatory support - MCS) to uznana metoda leczenia pacjentów ze schyłkową, przewlekłą lub ostrą niewydolnością serca. W Klinice Kardiochirurgii i Transplantologii od 15 lat używany jest system o przepływie pulsacyjnym POLCAS, w ostatnich latach coraz częściej zastępowany mechanicznym wspomaganiem krążenia o przepływie ciągłym II i III generacji (HeartMatell, HeartWare). Omawiany typ MCS obarczony jest znacznym ryzykiem powikłań i budzi coraz więcej kontrowersji wśród lekarzy. W pracy przedstawiono i oceniono wyniki leczenia systemem POLCAS w Instytucie Kardiologii w 2014 r.

Materiat i metody: Od stycznia do grudnia 2014 r. w Instytucie Kardiologii system POLCAS implantowano 12 chorym w wieku od 16 do 63 lat (42 \pm 17 lat). U wszystkich chorych obserwowano rozpoczynający się bądź pełnoobjawowy wstrząs kardiogenny. Czworo z analizowanych chorych (33\%) wymagało wcześniejszego wspomagania układu krążenia innymi urządzeniami, IABP $(n=2)$ lub ECMO $(n=2)$. W przypadku 3 pacjentów odnotowano przynajmniej jeden epizod nagłego zatrzymania krążenia, u 3 wystąpiły inne poważne zaburzenia rytmu mające wpływ na przyspieszenie decyzji o implantacji MCS. Prezentowane dane zostały retrospektywnie uzyskane z systemu informatycznego CliniNet Instytutu Kardiologii. Do analizy badanej populacji użyto arkusza kalkulacyjnego OpenOffice Calc.

Wyniki: Średni czas pozostawania na wspomaganiu układu krążenia wyniósł $41 \pm 25$ dni (od 15 do 91 dni). Przeżycie do czasu transplantacji bądź wyszczepienia MCS wyniosło 91,67\%. Podczas terapii najczęściej obserwowano następujące powikłania: tamponadę lub krwawienia wymagające interwencji - 25\% ( $n=3)$, niewydolność nerek wymagającą dializoterapii - 25\% ( $n=3)$, udar niedokrwienny ośrodkowego układu nerwowego związany z MCS - 16,6\% $(n=2)$, bakteriemię - 16,6\% $(n=2)$, infekcję rany $8 \%(n=1)$. Nie zanotowano awarii urzą-

Address for correspondence: Mateusz Kuć, Department of Cardiac Surgery and Transplantation, Institute of Cardiology, 26 Alpejska St., 04-628 Warszawa, phone: +48 600681 086, e-mail: matheuskuc@gmail.com 
Conclusions: The POLCAS heart assist system is an effective method of treatment as a bridge to transplantation or recovery in patients with end-stage heart failure. Early survival after the treatment remains at a satisfactory level. The main problem is the large number of complications related to the therapy. Key words: POLCAS, mechanical circulatory support, MCS.

\section{Introduction}

Heart failure can be defined as an abnormality of cardiac structure or function leading to failure of the heart to deliver oxygen at a rate commensurate with the requirements of the metabolising tissues despite normal filling pressures (or only at the expense of increased filling pressures) [1]. Heart failure occurs in about $1-2 \%$ of the adult population [2], while the number of patients with end-stage circulatory failure is on the rise [3]. Mechanical circulatory support with the use of left ventricular or biventricular assist devices (LVAD, BiVAD) is dedicated to patients in the terminal stage of the disease.

Taking into consideration the number of heart transplantations, which has not changed for several years [4], and the growing number of patients with end-stage heart failure awaiting the procedure, the dynamic growth of mechanical circulatory support techniques seems understandable [5]. Modern continuous-flow pumps are used not only as a bridge to transplantation or recovery, but may also serve as a destination therapy for individuals who do not qualify for transplantation $[6,7]$.

Pulsatile-flow mechanical circulatory support is being gradually removed from the medical market and replaced by continuous-flow pumps. The drawbacks of the POLCAS-type systems include the immobilisation of the patient, the number of complications increasing with the duration of therapy, and the necessity of involving a large treatment team. The results presented in this study, however, confirm the effectiveness of pulsatile-flow pumps in short- and long-term therapy used as a bridge to myocardial transplantation or recovery [8-10]. It appears that, due to the still significantly limited access to modern circulatory support systems, the analysed type of device may remain in use as a last-line therapy for endstage circulatory failure patients.

Pulsatile-flow mechanical circulatory support is a relatively well-studied method for the treatment of end-stage heart failure. Due to the large number of complications, it is becoming increasingly controversial among doctors. The aim of this work is to present and assess the results of treatment employing the POLCAS system, implemented at the Institute of Cardiology in Warsaw in 2014. dzenia. U pacjentów po planowym zakończeniu terapii MCS wczesne przeżycie, definiowane jako wypis do domu, wyniosło $63,6 \%(n=7)$.

Wnioski: System wspomagania serca POLCAS jest skutecznym sposobem leczenia jako pomost do transplantacji (bridge to transplantation) bądź regeneracji serca (bridge to recovery) u pacjentów z zaawansowaną niewydolnością krążenia. Wczesne przeżycie po zakończeniu terapii pozostaje na satysfakcjonującym poziomie. Głównym problemem pozostaje duża liczba powikłań związanych z terapią.

Słowa kluczowe: POLCAS, mechaniczne wspomaganie krążenia, MCS.

\section{Equipment used}

The first Polish circulatory support system, POLCAS, was composed of a POL-PDU 401 control unit and a POLVAD-MEV extracorporeal pulsatile cardiac support pump equipped with unicuspid valves produced by SORIN. It was used for the first time on January 27, 1999 in Zabrze (LVAD) and, two days later, at the Institute of Cardiology in Warsaw (BiVAD). The systems currently used by the Department of Cardiac Surgery and Transplantation at the Institute of Cardiology utilise the same modernised POL-PDU 401-1 control devices and POLVAD-MEV extracorporeal ventricles with bicuspid valves manufactured by SORIN. The POLCAS system has been used in 258 patients to date, including 181 patients of the Institute of Cardiology. The Department of Cardiac Surgery and Transplantation is currently in possession of four POLCAS systems. Before the beginning of therapy with the POLCAS system, all patients exhausted all other medical treatment options and were in a condition that posed a direct danger to their life. All decisions concerning the implantation were made by a HeartTeam. The decisions concerning the implantation of biventricular assist devices (BiVAD) were dependent on the stage of right ventricular failure. Cardiac support in the BiVAD configuration was used in $41.7 \%(n=5)$ of patients. The device was implanted via classic median sternotomy. In the case of left ventricular support, the inflow cannula was always placed in the apex of the heart. The outflow cannula ended in a graft, which was implanted into the ascending aorta. In the BiVAD support mode, the above configuration was supplemented with an additional inflow cannula located in the right atrium and an outflow cannula ending in a graft implanted into the pulmonary trunk. No inflow cannulas were implanted into the left atrium.

\section{Material and methods}

In the period from January to December 2014, the POLCAS system was implanted in three female (25\%) and nine male patients (75\%) aged 16-63 years (mean $42 \pm 17$ years). All patients provided their informed consent to the treatment with the POLCAS system; in the case of underage patients, the consent was signed by their caregivers as well. The patients were qualified for MCS implantation 
by the HeartTeam. Implantation of the devices was conducted by doctors from the Department of Cardiac Surgery. After implantation, patient care was provided by doctors and perfusionists from the Department of Cardiac Surgery, the Department of Anaesthesiology and Intensive Therapy, and the Department of Heart Failure and Transplantation. Each member of the team input data from their own area of expertise into the system. With regard to age, the size of the patients' ventricles $(70 \mathrm{ml})$ constituted a limitation in qualifying patients for the therapy, as it should be correlated with the body mass and height of the patient. Significant arrhythmias accelerating the decision concerning MCS implantation occurred in $50 \%(n=6)$ of patients, including cardiac arrest in three patients (25\%). Before MCS implantation, circulatory support with an intra-aortic balloon pump or ECMO was applied in $33 \%(n=4)$ of patients (Table I). All patients fulfilled the criteria established by the ESC for MCS implantation (New York Heart Association class IV without response to treatment provided for at least 60-90 days, LVEF < 25\%, dependence on intravenous inotropic therapy, PCWP $\geq 20 \mathrm{mmHg}$ and SBP $\leq 80-90 \mathrm{mmHg}$ or $\mathrm{Cl} \leq 2 \mathrm{l} / \mathrm{min} / \mathrm{m}^{2}$ ) [1]. Univentricular systems (LVAD) were implanted in seven patients, and BiVAD - in five patients. In two cases, RVAD was additionally implanted after the initial implantation of LVAD due to features of left ventricular failure.

\section{Results}

\section{Survival}

In the case of eleven patients (91.7\%), the initial therapeutic goal was a bridge to transplantation. In one patient, BiVAD implantation was performed in the course of myocarditis (bridge to recovery). Due to the lack of recovery features during the therapy, the qualification was changed and the patient underwent heart transplantation. Mechanical circulatory support implantation was not performed as a destination therapy. In two patients initially qualified for OHT, MCS explantation was performed under the assumption that the myocardium was partially regenerated and capable of ensuring haemodynamic stability. One of these patients (LVAD), with diagnosed postinflammatory cardiomyopathy, was discharged in good general condition; another patient (BiVAD), with diagnosed dilated cardiomyopathy of unknown aetiology, died during further hospitalisation. Heart transplantation was conducted in nine patients $(75 \%)$ in the analysed population. In this group, LVAD was implanted in five patients (55.5\%), and BiVAD in four patients (44.4\%). Six patients (66.67\%) after heart transplantation were discharged in good general condition, while three patients (33.3\%) died: two during further hospitalisation (LVAD, BiVAD) and one during heart transplantation surgery (BiVAD). In the entire analysed population, 11 patients $(91.67 \%)$ survived circulatory support with the POLCAS system; one death was reported (8.3\%) (LVAD). Seven patients were discharged in good general condition (58.3\%), while four patients (33.3\%) died during further hospitalisation. The average POLCAS system support time was $41 \pm 25$ days (15-91 days).

\section{Complications associated with the device}

The average working time of a ventricle was $20 \pm 17$ days for LVAD and $25 \pm 15$ days for RVAD. The longest working time of a single ventricle was 74 days for LVAD and 43 days for RVAD; the shortest time was 2 days for LVAD and 13 days for RVAD. On average, each patient underwent $2 \pm$ 1.4 ventricle replacements in the LVAD position. The highest number of ventricle replacements was performed in a 58-year-old patient with ischemic cardiomyopathy - 5 replacements during 58 days of circulatory support (Table II). All ventricle replacements were dependent on the presence of thrombi in the ventricular lumen. The complications that occurred during circulatory support included: tamponade or bleeding requiring intervention - $25 \%(n=3)$, renal failure requiring dialysis $-25 \%(n=3)$, central nervous system ischaemic stroke associated with MCS $-16.6 \%(n=2)$, bacteraemia $-16.6 \%(n=2)$, and wound infection - $8 \%(n=1)$. No device malfunctions were reported (Table II).

\section{Discussion}

On December 2, 1982, at the University of Utah, the first Jarvik 7 pneumatic heart prosthesis was implanted. The patient survived 112 days. Seventeen years later, the POLCAS system was used for the first time in Zabrze and, two days later, at the Institute of Cardiology in Warsaw.

Despite almost 15 years of experience, the use of mechanical circulatory support still remains a significant challenge in Poland. It requires the effort of numerous specialists and entails high financial expenditure. The awareness of the treatment process, the selection of patients, and the decision to implant the device is always associated with

Tab. I. Types of circulatory support before the use of the POLCAS system

\begin{tabular}{llcc} 
Age & Diagnosis & Type of support & Total support time \\
30 & Postinflammatory cardiomyopathy & IABP LVAD & 66 days \\
\hline 23 & Dilated cardiomyopathy & IABP LVAD & 18 days \\
\hline 42 & Dilated cardiomyopathy & ECMO LVAD & 37 days \\
\hline 24 & Dilated cardiomyopathy & ECMO BiVAD & 46 days \\
\hline
\end{tabular}

IABP - intra-aortic balloon pump, LVAD - left ventricular assist devices, OHT - orthotopic heart transplantation, ECMO - extracorporeal membrane oxygenation, BiVAD - biventricular assist devices 
Tab. II. Description of the adverse events occurring during the therapy with the POLCAS system

\begin{tabular}{cccccccccccccc} 
No. Age & $\begin{array}{c}\text { Used } \\
\text { ventricles } \\
\text { LVAD/ } \\
\text { RVAD }\end{array}$ & $\begin{array}{c}\text { Support } \\
\text { time } \\
\text { LVAD/ } \\
\text { RVAD }\end{array}$ & $\begin{array}{c}\text { Ischemic } \\
\text { strokes }\end{array}$ & $\begin{array}{c}\text { Generalized } \\
\text { brain } \\
\text { ischemia }\end{array}$ & $\begin{array}{c}\text { Bleeding/ } \\
\text { Tamponade } \\
\text { requiring } \\
\text { intervention }\end{array}$ & $\begin{array}{c}\text { Generalized } \\
\text { bacteremia }\end{array}$ & $\begin{array}{c}\text { Wound } \\
\text { infection }\end{array}$ & Dialysis & Total & Result \\
\hline 1 & 30 & $2 / 0$ & 63 & 0 & 0 & 0 & 0 & 0 & 0 & 0 & Explantation \\
\hline 2 & 44 & $1 / 1$ & 41 & 0 & 0 & 0 & 0 & 0 & 0 & 0 & OHT \\
\hline 3 & 54 & $4 / 0$ & 91 & 3 & 0 & 1 & 1 & 1 & 0 & 6 & Death \\
\hline 4 & 62 & $3 / 0$ & 24 & 0 & 0 & 0 & 0 & 0 & 0 & 0 & OHT \\
\hline 5 & 29 & $1 / 1$ & 15 & 0 & 0 & 0 & 0 & 0 & 1 & 1 & OHT \\
\hline 6 & 42 & $3 / 0$ & 30 & 0 & 0 & 0 & 0 & 0 & 0 & 0 & OHT \\
\hline 7 & 63 & $1 / 1$ & $21 / 13$ & 0 & 0 & 0 & 0 & 0 & 0 & 0 & OHT \\
\hline 8 & 58 & $5 / 0$ & 58 & 0 & 0 & 0 & 0 & 0 & 0 & 0 & OHT \\
\hline 9 & 24 & $1 / 1$ & $43 / 43$ & 1 & 0 & 3 & 1 & 0 & 1 & 6 & Explantation \\
\hline 10 & 54 & $1 / 0$ & 25 & 0 & 1 & 0 & 0 & 0 & 0 & 1 & OHT \\
\hline 11 & 23 & $2 / 0$ & 15 & 0 & 0 & 0 & 0 & 0 & 0 & 0 & OHT \\
\hline 12 & 16 & $1 / 3$ & $74 / 65$ & 0 & 0 & 2 & 0 & 0 & 1 & 3 & OHT \\
\hline
\end{tabular}

certain ethical concerns. This is one of the reasons why the present publication came into being. The presented work is a retrospective compilation of the results of treatment with the POLCAS system at the Institute of Cardiology in Warsaw in 2014. The patients undergoing the above therapy constituted a selected group of terminally ill patients with endstage heart failure with short expected survival time, usually in cardiogenic shock, despite optimal treatment. One patient died during the therapy; in two patients the device was explanted; $75 \%$ of patients $(n=9)$ underwent heart transplantation; seven patients (58.3\%) were discharged in good general condition. The most common complications included bleedings requiring surgical interventions, strokes caused by embolic material forming in the ventricles, infections, and renal failure. The presented results confirm the effectiveness of the therapy utilising pulsatile-flow pneumatic pumps in end-stage heart failure [7] as well as the main drawbacks of this method of support [11]. The devices used for pulsatile-flow mechanical circulatory support are gradually being replaced by the second and third generation of continuous-flow MCS equipment. The latter are characterised by a lower number of adverse events, longer complication-free therapy, and their possible use as a destination therapy [12-14]. From the surgeon's point of view, however, they are associated with certain technical difficulties during implantation in the BiVAD configuration. In the case of HeartWare devices, which are the most frequently implanted devices in Poland, the long inflow part in the RVAD position is problematic. The pulmonary bed creates low resistance for continuous-flow MCS, which may result in lung oedema [15]. Therefore, the synchronisation of both third-generation devices in the BiVAD mode of support is a difficult task for the attending physician.

\section{Conclusions}

The present work shows the results of the treatment of end-stage heart failure with the extracorporeal POLCAS circulatory support system at the Institute of Cardiology in Warsaw in 2014. Twelve patients participated in the analysis. The most frequent complications included ischaemic stroke and cardiac tamponade or bleedings requiring surgical intervention. In two patients, the device was explanted under the assumption that the heart was fit enough to ensure haemodynamic stability in the body; nine patients underwent heart transplantation; one patient died during the therapy; and seven patients were discharged in good general condition. Pulsatile-flow mechanical circulatory support is being gradually removed from the medical market and replaced by continuous-flow pumps. The drawbacks of the POLCAS-type systems include the immobilisation of the patient, the number of complications increasing with the duration of therapy, and the necessity of involving a large treatment team. Notwithstanding, the results presented above confirm the effectiveness of pulsatile pumps, especially in short- or medium-term therapy. Taking into consideration the still significantly limited access to modern circulatory support systems, we believe that pulsatile-flow MCS may remain in use as a last-line therapy for end-stage circulatory failure patients.

\section{Disclosure}

Authors report no conflict of interest.

\section{References}

1. Wytyczne ESC dotyczące rozpoznania oraz leczenia ostrej i przewlekłej niewydolności serca na 2012 rok. Kardiol Pol 2012; 70, supl. II: 101-176; http://www.ptkardio.pl/Wytyczne_ESC_dotyczace_rozpoznania_oraz_ leczenia_ostrej_i_przewleklej_niewydolnosci_serca_na_2012_rok-1821.

2. Mosterd A, Hoes AW. Clinical epidemiology of heart failure. Heart 2007; 93: 1137-1146.

3. McCullough PA, Philbin EF, Spertus JA, Kaatz S, Sandberg KR, Weaver WD. Confirmation of a heart failure epidemic: findings from the Resource Utilization Among Congestive Heart Failure (REACH) study. J Am Coll Cardiol 2002; 39: 60-69.

4. www.poltransplant.org.pl 
5. Aurora P, Edwards LB, Kucheryavaya AY, Christie JD, Dobbels F, Kirk R, Rahmel AO, Stehlik J, Hertz MI. The Registry of the International Society for Heart and Lung Transplantation: thirteenth official pediatric lung and heart-lung transplantation report - 2010. J Heart Lung Transplant 2010; 29: 1129-1141.

6. Kirklin JK, Naftel DC, Pagani FD, Kormos RL, Stevenson LW, Blume ED, Miller MA, Timothy Baldwin J, Young JB. Sixth INTERMACS annual report: a 10,000-patient database. J Heart Lung Transplant 2014; 33: 555-564.

7. Rose EA, Gelijns AC, Moskowitz AJ, Heitjan DF, Stevenson LW, Dembitsky W, Long JW, Ascheim DD, Tierney AR, Levitan RG, Watson JT, Meier P, Ronan NS, Shapiro PA, Lazar RM, Miller LW, Gupta L, Frazier OH, Desvigne-Nickens P, Oz MC, Poirier VL. Long-term use of a left ventricular assist device for endstage heart failure. N Engl J Med 2001; 345: 1435-1443.

8. Navia JL, McCarthy PM, Hoercher KJ, Feng J, Jeevantham R, Smedira NG, Banbury MK, Blackstone EH. Do left ventricular assist device (LVAD) bridgeto-transplantation outcomes predict the results of permanent LVAD implantation? Ann Thorac Surg 2002; 74: 2051-2062.

9. Frazier OH, Rose EA, Oz MC, Dembitsky W, McCarthy P, Radovancevic B, Poirier VL, Dasse KA; HeartMate LVAS Investigators. Left Ventricular Assist System. Multicenter clinical evaluation of the HeartMate vented electric left ventricular assist system in patients awaiting heart transplantation. J Thorac Cardiovasc Surg 2001; 122: 1186-1195.

10. Sun BC, Catanese KA, Spanier TB, Flannery MR, Gardocki MT, Marcus LS, Levin HR, Rose EA, Oz MC. 100 long-term implantable left ventricular assist devices: the Columbia Presbyterian interim experience. Ann Thorac Surg 1999; 68: 688-694.
11. Lietz K, Long JW, Kfoury AG, Slaughter MS, Silver MA, Milano CA, Rogers JG, Naka Y, Mancini D, Miller LW. Outcomes of left ventricular assist device implantation as destination therapy in the post-REMATCH era:implications for patient selection. Circulation 2007; 116: 497-505.

12. Slaughter MS, Rogers JG, Milano CA, Russell SD, Conte JV, Feldman D, Sun B, Tatooles AJ, Delgado RM 3rd, Long JW, Wozniak TC, Ghumman W, Farrar DJ,Frazier OH; HeartMate II Investigators. Advanced heart failure treated with continuous-flow left ventricular assist device. N Engl J Med 2009; 361: 2241-2251.

13. Miller LW, Pagani FD, Russell SD, John R, Boyle AJ, Aaronson KD, Conte JV, Naka Y, Mancini D, Delgado RM, MacGillivray TE, Farrar DJ, Frazier OH; HeartMate II Clinical Investigators. Use of a continuous-flow device in patients awaiting heart transplantation. N Engl J Med 2007; 357: 885-896.

14. Aaronson KD, Slaughter MS, Miller LW, McGee EC, Cotts WG, Acker MA, Jessup ML, Gregoric ID, Loyalka P, Frazier OH, Jeevanandam V, Anderson AS, Kormos RL, Teuteberg JJ, Levy WC, Naftel DC, Bittman RM, Pagani FD, Hathaway DR, Boyce SW; HeartWare Ventricular Assist Device (HVAD) Bridge to Transplant ADVANCE Trial Investigators. Use of an intrapericardial, continuous-flow, centrifugal pump in patients awaiting heart transplantation. Circulation 2012; 125: 3191-3200.

15. Krabatsch T, Drews T, Potapov E, Weng Y, Pasic M, Hetzer R. Different surgical strategies for implantation of continuous-flow VADs-Experience from Deutsches HerzzentrumBerlin. Ann Cardiothorac Surg 2014; 3: 472-474. 